\title{
The Muslim Brotherhood in Egypt: Ideology vs. Pragmatism
}

\author{
David Schwartz \\ Bar-Ilan University, Ramat Gan, ISRAEL \\ Department of Political Science \\ Daniel Galily \\ South-West University "Neofit Rilski”, Blagoevgrad, BULGARIA \\ Faculty of Philosophy, Department of Philosophical and Political Sciences
}

Received: 24 February 2021 • Accepted: 17 April 2021 - Published Online: 19 April 2021

\begin{abstract}
This study aims to present the Muslim Brotherhood in Egypt, its ideology and pragmatism. With progress and modernization, the Islamic movements in the Middle East realized that they could not deny progress, so they decided to join the mainstream and take advantage of technological progress in their favor. The movement maintains at least one website in which it publishes its way, and guides the audience. Although these movements seem to maintain a rigid ideology, they adapt themselves to reality with the help of many tools, because they have realized that reality is stronger than they are. The main points in the article are: The status of religion in the country; What is the Muslim Brotherhood? According to which ideology is the movement taking place? Movement background and ideology; Theoretical background - The theory of Pragmatism; How is pragmatism manifested in the activity of the Muslim Brotherhood in Egypt? In conclusions: The rise of the Islamist movements as a leading social and political force in the Middle East is the result of the bankruptcy of nationalism, secularism and the left in the Arab world, which created an ideological vacuum, which is filled to a large extent by the fundamentalists, ensuring that Islam is the solution. It is not only about the extent of the return to religion, but about the transformation of religion into a major political factor both by the regimes and by the opposition. These are political movements that deal first and foremost with the social and political mobilization of the masses, and they exert pressure to apply the Islamic law as the law of the state instead of the legal systems taken from the Western model.
\end{abstract}

Keywords: Muslim Brotherhood, Egypt, ideology, pragmatism.

\section{Introduction}

Egypt is very large, but most of its inhabitants live densely in the Nile Valley and the Delta, since these are areas that deserve to live. The majority of the population, close to 78 million, is Muslim and a small Christian minority. Natural increase in Egypt is one of the highest in the world, although there has been a decline, which will cause the population to double over the next 25 years. Since 1945 there has been an accelerated process of urbanization, but it is a destructive process since there is no infrastructure for absorbing the masses, which ultimately end up as

(C) Authors. Terms and conditions of Creative Commons Attribution 4.0 International (CC BY 4.0) apply. Correspondence: David Schwartz, Bar-Ilan University, Department of Political Science, Ramat Gan, ISRAEL. E-mail: dvd99@015.net.il. 
unemployed or homeless on the margins of society, and they are the basis of radical Islam. Today, the economic aid provided by the United States to Egypt is necessary, as it avoids hunger and social unrest, and the tourism sector is a major and important source of income for Egypt, but the terrorist elements are aware of this and are trying to harm tourism in order to harm the economy. The state economy and privatization. Egypt is carrying out large-scale development projects, such as the construction of the Aswan dam, which has provided jobs, and provides electricity to thousands of villages, but development programs are not keeping pace with population growth. Industrialization is also difficult because most of the population is unskilled and almost half of the population is illiterate. The improvements in the economic situation in Egypt have not yet affected the standard of living of the masses and the weaker sectors of the population, which are a convenient place for radical Islamic movements. Egypt is a country with elements of democracy, but it is not democratic, since the state intervenes in all areas and there is no separation of powers. Also, the media is still under strict supervision, and most of the media is owned by the government (Ajami, 1983).

\section{The status of religion in the country}

During the reign of President Sadat, who was a devout believer, and spread and publicizes the government's efforts to develop and strengthen the Islamic prayer and education institutions and adopt clear Islamic law principles, the influence of the religious opposition in Egypt was on the rise, with the movement of "repentance" to fundamentalist Islam encompassing tens of thousands. While the Egyptian people underwent a shake-up in "modern" Egypt, Islam remained a solid rock and the return was like a retreat to the safe and familiar haven. Many joined Islam and Islamic organizations in protest against the material-economic situation. Others came to the Islamic movements as a result of spiritual emptiness and lack of direction. The movements offered their members a world view of equality, a simple way of life, a spiritual peace within religious piety when they were promised a change from the intolerable reality. The main victims of material and ideological distress are students at universities that have become the main stronghold of the Islamic opposition.

Sadat left Mubarak a government framework that functions relatively efficiently, and the economic situation of the country was better than what Sadat received from Nasser. The government faced a fundamentalist Islamic opposition, so that Egyptian society at the beginning of Mubarak's reign continued to oscillate between the three main components of personal consciousness: Islam-Egyptian-Arab.

After Sadat's assassination, Vice President Hosni Mubarak was president and head of the ruling National Democratic Party. Mubarak was elected president in four other elections, in 1987, in 1993, in 1999 and in 2005. Sadat's successor continued the peace policy taken by his predecessor.

When he was appointed president, he emphasized the difference between his policy and Sadat's policy: he blocked the rush towards a free market economy, stopped liberalization in the economy, and returned to more state supervision; On the other hand, a greater degree of freedom allowed political organization and opposition to power. Mubarak's policy has led to tourism and economic development, but due to the high rate of natural increase in Egypt, economic growth is not yet absorbing the needs of the population.

In the area of foreign relations, Mubarak continued to nurture Egypt's ties with the United States and at the same time rehabilitated relations with Russia, mainly seeking to improve relations with the Arab states, which were undermined by the peace treaty with Israel and restoring Egypt to its traditional role as leader of the Arab world. In contrast to his moderate foreign policy, Mubarak has been working hard in recent years against radical Islamic 
organizations in Egypt. Islam in Egypt rises in its influence on democracy. It is a deep belief, and Islam is also known to the uneducated classes, and is embedded in the blood of culture and underlies the way of life and education. Democracy, on the other hand, has no basis in political history, political culture or dominant civil culture. In contrast to Islam, democracy is linked to Western failure, which has led to the destruction of traditional norms. The pursuit of democracy has historically stemmed from the conviction that this system is one of the components of Western supremacy.

It can be seen that Egypt is undergoing a revolution in power and even a push for democracy. The continuation of the transition and trend of change can also be seen in recent times, in 2005 in the first multi-national elections in Egypt.

The reality gave Mubarak a face, he received from Sadat a country that was completely boycotted by the Arab states, a state in which tension exists between regime and opposition and other ethnic and social tensions, he manages to stabilize Egypt and bring back the heart of the Arab world.

Mubarak softens the internal tension and stops the opposition's persecution, but the course of events is dynamic, and in Egypt today there is a weariness from Mubarak's rule. One of the most prominent is the personal aspect, the top of the government is stagnant, most of the officials are still appointed by the president, newspaper editors, senior generals and leading people in society, economy, culture and entertainment.

Sadat has led a process of disengaging from Nasser's socialist heritage and closer to the West. The move has not been completed, and there is a price to this - in society there are large gaps between the classes. Mubarak does not present a structured world view of Egypt's character. In this way, the regime acquiesced in social phenomena and even encourages some of them. Belief in failure to act as a guarantee of economic survival and stability, but also has disadvantages.

Islamic movements flourished against the oppression of civil society during Mubarak's time, when they could flourish under the protection of mosques and religious institutions. The pressure exerted by the Islamic movements on the government led to limited democratization, which allowed limited freedom of organization and political participation to opposition parties.

At the same time, Islamic movements exploited this possibility of political participation when they compromise and accept the state and territory as an arena of activity. Defining the goals was less a change of regime and more - Islamic society, a kind of coexistence between the territorial state and the Islamic values.

Fundamentalism conducts a battle of bravery against modernism, but is forced to compromise with reality. The leaders of radical Islam accepted the fact that a classical Islamic state could not be established, complemented by modern technology, and even exploited it to advance their interests. This is due to the technology that advances the achievement of Islam's goals and the system of preaching. Despair and disappointment the powerlessness of the government paved the way for the message of radical Islam. The young generation, as a result of economic and social distress, turned to seek the lost Arab honor. Fundamentalism works to achieve its goals in political ways, so they must compromise and act pragmatically, for example, with regard to technological progress, since they know that reality is stronger than them, but God's sovereignty is not subject to compromise, and society must live according to Sharia. The extremist movements and the regimes against them are operating.

The rulers of Egypt along the time axis are aware of the danger inherent in the Muslim Brotherhood, and therefore defined them as the primary enemy and as a strategic threat to the stability of the regime, since they present themselves as a classic Islam rather than an exceptional and fanatic factor. In Egypt, in fact, since the officers' revolution, there has been a struggle between the secular regime and the Islamic movement in Egypt, a struggle that has involved thousands of 
arrests and executions over the years. Mubarak was defined by the Muslim Brotherhood as a ransom to be cleared in order to prepare the way for the establishment of an Islamic State the Egyptian regime acted in response to brutal oppression and persecutions, thus reducing violence, but the use of such force led to temporary calm and subsequent calamity.

The main problem in the Arab countries is that there have been no political developments or a real improvement in the socio-economic sphere that has led to the establishment of a new movement that will replace radical Islamic movements, so radical Islam will continue to be a threat to the secular Arab regimes (Mura, 2012).

3. What is the Muslim Brotherhood? According to which ideology is the movement taking place? - Movement background and ideology

The Muslim Brotherhood was founded in 1929 by Hassan al-Banna in Ismailia. Following his view of the corruption prevalent in society, especially among the youth, as well as the economic, social and political inferiority of Egypt, he decided to establish a movement that would deal with education and correcting the situation. The movement is trying to bring Egypt back to the beginning of Islam, to the era of glamor, according to the Shari'a, the conditions prevailing in Egypt in those years, unemployment and distress caused the movement to grow easily. The Islamic message was easily absorbed in a frustrated society suffering from social and economic distress. Between religious and secular. The Muslim Brotherhood has become an orthodox urban movement, a regular movement designed to correct certain injustices in the name of religious norms. It is a modern political party with a systematic organization, a mechanism for mobilizing organized supporters, and a clear political platform. To mobilize the masses, the organization is supported by ideological persuasion, welfare and welfare programs, along with an organized banking system and Islamic investment. Hassan al-Banna established a military organization within the framework of the Muslim Brotherhood. This was particularly significant, as this indicated the Muslim Brotherhood's willingness to achieve its goals in violent ways as well.

Ideologically, the Muslim Brotherhood claims that the Muslim world is at an unprecedented low. This is because Islam has absorbed foreign influences that have corrupted the original message and corrupted the inhabitants of the Muslim world. As a movement that advocates patriotism, the brothers saw a special connection between Egypt and the movement. This attitude was also due to Egypt's dismal situation as a sign of the bleak situation in the entire Muslim world. They argue that the British control of Egypt instilled in Egyptian society the maladies of Western society, and led to moral corruption of the entire Egyptian society. The imperialist Western world that advocated liberalism was infected with moral corruption that affected Egyptian society and the world (Robinson, 2010).

The only solution to the situation in which the Muslim world is located consists of two stages. In the first stage, Western imperialism must be expelled and all its ideas rejected. Second, Islam must be purged of all foreign influences and returned to Muhammad's initial message. After these two goals have been achieved, the glorious days of Islam must be renewed and the Islamic caliphate should be reestablished. But as an interim step towards achieving the ultimate goal, namely, the reestablishment of the Islamic caliphate, an Islamic order must be established in Egypt. The establishment of an Islamic order that would include the elimination of separation between religion and state, which is impossible for the Brotherhood, and the application of Sharia's - Islamic law as the constitution of Egypt.

According to the doctrine of the Muslim Brotherhood, these goals will be achieved gradually by training the hearts, in proper preparation for the establishment of an Islamic religious state. The training of hearts will be done through the following activities: preaching, education, direction, preparation and preparation for jihad. Educational institutions will be established that 
will educate the generation of sorrow in the Islamic way of life. In the country, an Islamic way of life will be instituted in all spheres of life. In addition, a preaching system will be introduced to educate the population regarding the Islamic message.

After a while, the movement that started from the bottom emerged, and also entered the political framework in order to reform society and the government in the spirit of Islam. Members of the movement began to incite various elements in Egypt against the government, and were also involved in political murders, such as Egyptian Prime Minister Al Nukrashi in 1949. On 12 February, Al-Banna was assassinated in retaliation for the murder of Egyptian Prime Minister Nukarashi by the Muslim Brotherhood.

During the first year of the Free Officers' transformation, there was good relations between the movement and the officers. However, from the middle of 1953, when it became clear that the Revolutionary Council was moving towards a secular state rather than an Islamic state, relations deteriorated. The crisis between the Muslim Brotherhood and Nasser broke out with the understanding that he held socialist and secular ideas. On October 26, 1954, in light of Nasser's assassination attempt, the movement was outlawed and severely oppressed (Badrul, 1982).

\section{Theoretical background - The theory of pragmatism}

Pragmatism is a philosophical theory that was raised in the United States at the end of the 19 th century. Its founders were Charles S. Pierce, who gave the theory its name and developed its principles, William James, who promoted and disseminated it, and John Dewey, who developed the instrumental aspects of the theory (Bacon, 2012). The theory of pragmatism is a philosophical idea that emphasizes the connection between theory and practice: the value of the truth of theory depends on the organization and the effectiveness of its application. Pragmatism, says Richard Rorty, is about what are the most effective ways of achieving what we want to achieve (Brandon, 2011).

Pragmatism holds that the truth is measured by practical purposes. The truth of a claim is determined by practical results and the benefit it serves. Pragmatists rely on empirical experiments and practical success and rejecting a-priori assumptions as a source of human knowledge (espousing empiricism). According to pragmatism, thoughts, ideas, and outlooks are merely tools for achieving one's life goals - and have no metaphysical significance (Kloppenber, 1996).

That is, concepts represent appropriate thinking habits or etiquette; they do not represent metaphysical truths and do not describe the nature of things. Language is not only a means of communication but an expression of the world's consciousness and worldview. Knowledge is guided by the interests and values of users. The subjects establish themselves in a process of empirical experience, rather than as a result of rational and theoretical inquiry (Menand, 1998).

5. How is pragmatism manifested in the activity of the Muslim Brotherhood in Egypt?

The Muslim Brotherhood sometimes acts within the framework of the law, when it is possible and convenient, and sometimes undermines it for their own purposes. Their activities are directed against the state and its institutions, and as part of this they seek to infiltrate the ranks of the army and the police in order to take control of it, with the ultimate goal of creating an Islamic state. As part of its activity, the dilemma between the Pan-Islamic idea and the national point of view often arose. The regimes in Egypt from the beginning of the century aspired to the existence of a territorial nation-state, based on a system of law and bureaucracy according to the Western 
model. During the Mubarak era, relations with the West, especially the US, became closer to Egyptian economic cooperation and dependence.

How does a movement such as the Muslim Brotherhood cope with such a world view?

Since the 1980s, the movement, as befits an Islamic movement, has adopted the principles of the Sabra, a long-term strategy that will lead to a goal, i.e., an Islamic state. And thus, to be able to organize themselves as a party, since they were prohibited from organizing as an independent political party, so they succeeded in entering the People's Council in 1984 and 1987 and gained political achievements when their issues were placed on the agenda in the public (Murphy, 2007).

The Muslim Brotherhood has often faced the regime without violence at all, making it difficult for the regime to fight them. The regime, which understood that the threat was on Egypt's long-term stability, began to fight the brothers in the political arena and prevented them from running in the elections in 1990 and 1995, until finally they succeeded in eliminating them from the political field. Mubarak decided on a strategy of "total confrontation" and fought the religious movement without much success by enlisting his own clerics with counter-fatwas, and even using the strict laws that led to a deep internal crisis. In the first years of his term, Mubarak worked to increase democracy, made it possible to establish political parties, and expanded freedom of the press. He sought to reach a balance with the religious opposition, separating the moderates, ie, the Muslim Brotherhood, from the more extreme movements in which he fought with cruelty. Mubarak has been practicing Islamization, such as taxing alcohol, and increasing censorship on television. Moderate religious' activity was possible.

The regime needed to fill the religious vacuum in order to monitor religious services in the country and to provide the public with its religious needs. Therefore, Mubarak made a quiet alliance with them, so that the brothers would implement the shari'a without violence and without the regime's commitment to recognize them. The Muslim Brotherhood undertook to fill gaps for the regime and thus create a broader base of support because of its cooperation with the regime. The movement succeeds in threatening its stability. Over the years, the brothers have placed their own people in thousands of mosques in Egypt, in response to the regime's clerics. When Mubarak tried to nationalize some of the private mosques, those were left without worshipers, and this action caused unrest among the movement and among worshipers against the regime. The religious confrontation with the Brotherhood did not succeed in Egypt (Osman, 2010).

Another space that the Muslim Brotherhood has taken over is the socio-economic space by establishing schools and investment companies in the spirit of Islam, and the movement realized that because of the powerlessness of the government, and because these services are necessary for the state, And hospitals and boarding schools and schools at symbolic prices, where there was a huge shortage of these, and so the Islamic message went to the needy, the money that the movement earned from the investment companies was invested in Dawa, and the transmission of the Islamic message.

The government's inability to meet these needs provided a window of opportunity for Islamic activity. The regime knew that these bodies were necessary for the population, and therefore did not act decisively to close them. The movement exploits spaces in which the government cannot act against it. The willingness of the Muslim Brotherhood to participate in the democratic process is a compromise and a concession to the seizure of power by force. According to Hassan al-Bana's doctrine, the goal of fatwah is not only to reach the grassroots level, but also to the official level, namely, the People's Council, in which there is no separation between religion and state.

The main goal was to bring about the implementation of shari'a in the country. Participation in the People's Council serves the religious propaganda, and through the People's 
Council the hearts can be fixed. Thus, the brothers merged with a secular party, the Wafd, in the 1984 elections, and were successful. And later in 1987, together with the Amal Party and the Liberals. The brothers needed the umbrella of other parties because they were outlawed. The movement did not give up its funds, and its platform was that sharia would be the main source of legislation. This issue has always been on the agenda. The regime, for its part, rejected the numerous bills they had proposed, and introduced alternative bills. The regime expected that the brothers' power would weaken or participation in the democratic process would lead to division, but the opposite happened, and their influence and power increased. In 1990, following new laws of the regime designed to make the movement more difficult, it withdrew from the People's Council.

Thus, the Muslim Brotherhood was pushed into the trade unions by the government and found a great deal of activity for them, and the brothers had a very strong organizational capacity, and therefore they had a large sector of workers in their ranks. The unions served as an alternative arena, and once again they received a political platform to convey the Islamic message. If at first Mubarak supported coexistence, from 1994-5 he began a comprehensive confrontation with them in order to suppress and humiliate them and remove them from any influential framework. In 1995, the Brotherhood decided to run again in the elections to the People's Assembly, the regime pushed them through many arrests and interrogations, and pushed them into all areas of the trade unions, the media and the political arena. The leader of the movement, Hamed Abu Nasser, was very old and ill and could not unite the ranks, and after his death Mustafa Mashur was elected to replace him, and he decided to maintain a moderate and nonviolent policy like his predecessor and called on the regime to deal with The movement was a dialogue to resolve the conflict, and the youth of the movement opposed the dead road In the days of Nasser's oppression, the movement suffered from internal strife and faction, and the leader supported the path patiently and with patience, and before him the young people wanted strong action. The movement from the headlines, weakening and even causing internal friction between the veteran leadership and the young leadership (El Rashidi, 2011).

\section{Conclusions}

The rise of the Islamist movements as a leading social and political force in the Middle East is the result of the bankruptcy of nationalism, secularism and the left in the Arab world, which created an ideological vacuum, which is filled to a large extent by the fundamentalists, ensuring that Islam is the solution. It is not only about the extent of the return to religion, but about the transformation of religion into a major political factor both by the regimes and by the opposition. These are political movements that deal first and foremost with the social and political mobilization of the masses, and they exert pressure to apply the Islamic law as the law of the state instead of the legal systems taken from the Western model.

The Islamic solution offered by these movements has several distinct advantages over others. First, Islam is presented as a comprehensive system that provides all solutions to the problem of this world and the next. Second, the Islamic solution is presented as an alternative to the realization of Arab and Islamic revival and power. Ideas of Islamic movements tend to be inclusive, which increases their attractiveness. They are radical in that they seek seemingly profound solutions to the fundamental problems of society. Third, it is not an imported solution. The Islamic solution is an authentic one, rooted in local culture and suited to local conditions.

Islamists also use Da'wah to convey their message. In addition, the voluntary activity of the Islamic movements brings them closer to the general public, especially those in need of social services, education and medicine, and places the Islamic societies in an important position of influence. In the depression surrounding the alleys of poverty, Islam appears as a new hope and the slogan "Islam is the solution" does not require proof. 
The Islamic movements' main concern is traditional educational activity aimed at preserving and strengthening the character and Islamic character of society. One example of this is the Muslim Brotherhood movement in Egypt at the beginning of its path, which took the approach that the path to achieving the goal, i.e., the establishment of an Islamic state, is a gradual one, emphasizing the Islamic education of the younger generation. How can we explain the fact that the Islamic movements join the government and usually operate within the framework of the law? Most of the Islamic movements in the Arab countries are persecuted by the regime, so they must recognize reality, otherwise the government will not allow them to exist.

Islam is a belief rooted in the consciousness of the masses and deeply ingrained in Egyptian culture. In Israel, the situation is different, modernization and democracy also affect Israeli Arabs. Therefore, it is possible that Islam is not so deeply rooted in the culture of the Arab citizens of Israel, they are aware of the possibility of a different path other than Islam (Chukov, 2018).

Every movement as radical as it may be, tries to adapt itself to the changing realities and conditions, since their leaders know that without any support from the government, it will be difficult for them to exist (Petkova, 2012).

The movements have developed over time tools that enable them to cope with reality. The religious law in Islam allows flexibility in organizing community life, Sharia's is adapted to reality because of the ruler's ability to canonize legislation and flexibility in political life according to principles such as sabra and long-term goals, to compromise with reality and find temporary solutions, as well as religious scholars who provide fatwas and commentaries on every subject.

With progress and modernization, the movements realized that they could not deny progress, so they decided to join the mainstream and take advantage of technological progress in their favor. Each movement maintains at least one website in which it publishes its way, and guides the audience. Although these movements seem to maintain a rigid ideology, they adapt themselves to reality with the help of many tools, because they have realized that reality is stronger than they are.

Note: The article has been updated. Its first version was previously published in the Interdisciplinary Journal for Israel Studies (2017), which is no longer active today.

\section{Acknowledgements}

This research did not receive any specific grant from funding agencies in the public commercial, or not-for-profit sectors.

The authors declare no competing interests.

\section{References}

Ajami, F. (1983). In the Pharaoh's shadow: Religion and authority in Egypt. Islam in the political process. James P. Piscatori (Ed.) Cambridge University Press.

Bacon, M. (2012). Pragmatism. Oxford Polity Press.

Badrul, H. S. (1982). Syed Qutb Shaheed. Islamic Publications International, $2^{\text {nd }}$ ed. 
Brandom, R. (2011). Perspectives on Pragmatism: Classical, Recent, and Contemporary, MA: Harvard University Press.

Chukov, S. V. (2018). Political and philosophical discourse on the border between the Caliphate and terrorism - ISIS. 2nd International e-Conference on Studies in Humanities and Social Sciences (2IeCSHSS) - Conference Proceedings (pp. 59-74). Belgrade: Center for Open Access in Science. https://doi.org/10.32591/coas.e-conf.02.05059c

El Rashidi, Y. (2011). Egypt: The victorious Islamists. New York Review of Books. https://www.nybooks.com/articles/2011/07/14/egypt-victorious-islamists/.

Kloppenber, T. J. (1996). Pragmatism: An old name for some new ways of thinking? Source: The Journal of American History, 83(1), 100-138.

https://oconnell.fas.harvard.edu/files/jameskloppenberg/files/pragmatism old name for new wayas of thinking.pdf.

Menand, L. (Ed.) (1998). Pragmatism. New York: Random House. https://plato.stanford.edu/entries/pragmatism/

Mura, A. (2012). A genealogical inquiry into early Islamism: the discourse of Hasan al-Banna. Journal of Political Ideologies, 17(1).

https://www.tandfonline.com/doi/abs/10.1080/13569317.2012.644986?journalCode=cjpi20

Murphy, C. (2007). Passion for Islam: Shaping the Modern Middle East: The Egyptian Experience. Paperback.

Osman, T. (2010). Egypt on the brink: From Nasser to Mubarak. Yale University Press.

Robinson, F. (Ed.). (2010). The Islamic world in the age of western dominance. Cambridge University Press.

Petkova, T. (2012). The Arab Spring and the problems of the Schengen Area - in the monographic collection "Borders. In Philosophical and political readings [Петкова, Т., Арабската пролет и проблемите на Шенгенското пространство - в монографичен сборник Границите философски и политически прочити, стр. 64-74, Изд. “Фабер”, Велико Търново. България.] pp. 64-74, Faber Publishing House, Veliko Tarnovo. Bulgaria. ISBN 978-954-400$645^{-7}$. 
D. Schwartz \& D. Galily - The Muslim Brotherhood in Egypt: Ideology vs. Pragmatism

C O A $\mathbf{s}$ 